Widayat, D. · R. G. Yustisiyanika

\title{
Pengaruh dosis herbisida glifosat terhadap gulma, pertumbuhan, dan hasil tiga kultivar kedelai (Glycine max (L.) pada sistem tanpa olah tanah (TOT)
}

\section{Effect of glyphosate herbicides dose on weeds growth and yield of three cultivars of soybean in no tillage system}

Diterima : 15 September 2015/Disetujui : 15 Oktober 2015 / Dipublikasikan : Oktober 2015

CDepartment of Crop Science, Padjadjaran University

\begin{abstract}
The purpose of this experiment was determine the interaction effect between glyphosate herbicide dosage and cultivarsof soybean on weeds, growth and yield of soybean. The experiment was conducted at the experimental station Ciparanje, Padjadjaran University, Jatinangor, Sumedang. The experi-ment design used was Randomized Block Design with Factorial pattern consisting of two factors and three replications. The first factor was cultivarsof soybean consisting of three : Tidar, Burangrang, and Slamet. The second factors was glyphosate herbicide dosage consisting of three levels : 1,5 1/ha, 3,0 1/ha, and 4,5 1/ha. The result of this experiment showed that there was no interaction between varians of Soybean and glyphosate herbicide dosage on dry weight weed, height of plan at 2 and 4 weeks after planting, growth of soyabean 2-4 weeks after planting and yield components. There was effect on height of plan at 6 and 8 weeks after planting, growth of soyabean 4-6 and 6-8 weeks after planting.
\end{abstract}

Keywords : Age of soybean - Weed · Dosage · Glyphosate herbicide

Sari Penelitian ini bertujuan untuk mengetahui pengaruh interaksi antara dosis herbisida Glifosat dan kultivar kedelai terhadap gulma, pertumbuhan, dan hasil tanaman kedelai. Percobaan dilakukan di Kebun Percobaan Saung Meeting Ciparanje Universitas Padjadjaran Jatinangor, Kabupaten Sumedang. Rancangan percobaan

\footnotetext{
Dikomunikasikan oleh F.Y. Wicaksono

Widayat, D. ${ }^{1}$ - R. G. Yustisiyanika ${ }^{2}$

${ }^{1}$ Dept. Budadaya Pertanian Fakultas Pertanian Unpad

2 Alumni Program Pasca Sarjana Ilmu Tanaman Unpad

Korespondensi: widayatdedi@yahoo.com
}

yang digunakan adalah rancangan acak kelompok pola faktorial yang terdiri dari dua faktor dan diulang 3 kali. Faktor yang pertama adalah kultivar kedelai yang tediri dari tiga yaitu kultivar Tidar, Burangrang, dan Slamet. Faktor yang kedua dosis herbisida glifosat yang terdiri dari 3 taraf yaitu 1,5l/ha, 31/ha, dan 4,5l/ha. Kombinasi perlakuan kultivar dan dosis herbisida glifosat tidak memberikan pengaruh interaksi terhadap bobot kering gulma rumput,bobot kering daun lebar, bobot gulma total, tinggi tanaman 2 mst dan $4 \mathrm{mst}$, laju pertumbuhan tanaman 2 - 4 mst dan komponen hasil. Tetapi memberikan pengaruh interaksi pada tinggi tanaman umur 6 mst dan 8 mst serta pada laju pertumbuhan 4-6 mst dan 6-8 mst.

Kata kunci : Umur kedelai · Gulma · Dosis · Herbisida glifosat

\section{Pendahuluan}

Kedelai merupakan salah satu tanaman sumber protein yang penting di Indonesia. Berdasarkan luas panen di Indonesia kedelai menempati urutan ke-3 sebagai tanaman palawija setelah jagung dan ubi kayu (Suprapto, 2004).

Indonesia merupakan negara penghasil kedelai keenam terbesar di dunia. Namun dari segi produktivitasnya masih rendah, yaitu 1,1 ton/ha. Secara teoritis jika tidak ada hambatan apa pun maka potensi biologis produktivitas kedelai di Indonesia maksimum adalah 3-3,5 ton/ha.Di pihak lain, perkembangan produksi selama sepuluh tahun terakhir ternyata $73 \%$ di antaranya berasal dari sumbangan perluasan areal panen dan $27 \%$ dari peningkatan produktivitas (Rini Wudianto dan Adisarwanto, 2002) 
Berbagai kultivar kedelai dilepas di Indonesia, kultivar-kultivar tersebut memiliki umur panen yang berbeda-beda. Bila dikelompokkan ke dalam umur panen, kedelai memiliki tiga golongan besar yaitu : umur genjah yang memiliki waktu panen kurang dari 80 hari; umur sedang yang memiliki waktu panen $80-85$ hari; dan umur dalam yang memiliki waktu panen lebih dari 85 hari.

Respon tanaman terhadap persaingan dengan gulma tergantung pada kultivar masingmasing. Setiap kultivar memiliki ketahanan yang berbeda terhadap kompetisi dengan gulma maupun dosis herbisida yang akan digunakan, dikarenakan perbedaan umur menentukan lamanya periode kritis tanaman tersebut. Semakin lama umurnya semakin panjang periode kritisnya.

Penyebab rendahnya hasil kedelai adalah infestasi gulma secara liar pada tanaman kedelai mulai dari awal fase vegetatif sampai menjelang panen. Penurunan hasil kedelai akibat infestasi gulma bila tanpa dikendalikan berkisar antara 35-60 \% (Ardjasa dan Bangun, 1986 dalam A. Supriyo dkk., 1996)

Menurut Sumarni dan Wandri (2003) keberadaan gulma diantara tanaman dipengaruhi oleh sistem tanah. Pengolahan tanah merupakan pekerjaan modifikasi atau manipulasi tanah di daerah perakaran tanaman, yang secara langsung maupun tidak langsung mempunyai tujuan untuk mengendalikan gulma dan membentuk kondisi fisik tanah yang dikehendaki oleh tanaman (Nurmala, 2004). Salah satu alternatif untuk persiapan lahan yang ramah terhadap lingkungan adalah dengan sistem tanpa olah tanah (TOT).Menurut Barus (2003) pengolahan tanah dengan sistem tanpa olah tanah (TOT) yang menggunakan herbisida merupakan cara yang paling banyak dilakukan oleh para petani, karena cara ini dianggap lebih praktis dan hemat, terutama jika ditinjau dari segi kebutuhan tenaga kerja yang lebih sedikit dan waktu pelaksanaan yang relatif lebih singkat.

Sistem TOT dengan herbisida sangat efektif mengendalikan gulma dibandingkan dengan olah tanah konvesional, selain menghemat tenaga kerja, penggunaan herbisida dapat menekan pertumbuhan gulma berikutnya karena tertahannya perkecambahan biji gulma dari sisasisa gulma yang mati (Syngenta, 2002 dalam Fransisca Ayu Puspita Rini, 2005).

Glifosat merupakan herbisida sistemik tidak selektif sehingga mempunyai spektrum luas dalam pengendalian gulma. Senyawa tersebut diserap melalui daun dan ditranslokasikan ke semua jaringan tumbuhan serta mempengaruhi metabolisme asam nukleat dan sintesis protein (Sastroutomo, 1992 dalam Sulastri Anggorowati dan Sumarsono, 2003).

Untuk itu perlu dilakukan penelitian mengenai pemberian berbagai dosis herbisida glifosat terhadap gulma, pertumbuhan dan hasil tiga kultivar kedelai pada sistem tanpa olah tanah (TOT).

Adapun maksud dari penelitian ini adalah untuk mengkaji pengaruh pemberian herbisida glifosat pada berbagai tingkatan dosis terhadap gulma, pertumbuhan dan hasil tiga kultivar kedelai pada sistem tanpa olah tanah (TOT). Adapun tujuan dari penelitian ini adalah untuk menentukan dosis herbisida glifosat yang tepat sehingga gulma dapat ditekan dan pertumbuhan serta hasil tiga kultivar tanaman kedelai maksimal pada sistem tanpa olah tanah (TOT).

\section{Bahan dan Metode}

Penelitian dilaksanakan di kebun percobaan Ciparanje Jatinangor, Kabupaten Sumedang. Ketinggian tempat $\pm 750 \mathrm{~m}$ diatas permukaan laut, jenis tanah Inceptisol dan lokasi penelitian memiliki tipe curah hujan C (agak basah) berdasarkan klasifikasi Schmidt dan Ferguson (1951).

Bahan-bahan yang digunakan dalam penelitian ini antara lain : benih kedelai kultivar Tidar, Burangrang, dan Slamet, herbisida Toupan 220 AS dengan bahan aktif glifosat kalium $220 \mathrm{~g} / \mathrm{l}$, pupuk urea dengan dosis 50kg/ha, KCL dengan dosis 100 $\mathrm{kg} / \mathrm{ha}$, SP 36 dengan dosis $100 \mathrm{~kg} / \mathrm{ha}$, air, insektisida Decis 2,5 EC.

Alat-alat yang digunakan dalam percobaan ini antara lain : knapsack sprayer dengan nozel kuningan, besi kuadrat $(0,5 \times 0,5 \mathrm{~m})$ untuk analisis vegetasi, gelas ukur, cangkul, timbangan elektrik, oven, tali rafia, tugal, kantong plastik, label, mistar, kantong kertas, meteran, alat tulis.

Metode Percobaan yang digunakan dalam penelitian ini adalah rancangan acak kelompok faktorial, yang terdiri dari 9 perlakuan masingmasing diulang tiga kali sehingga diperoleh 27 satuan perlakuan.

Faktor yang pertama merupakan kultivar yang terdiri dari : k1: Kultivar Tidar, k2 : Kultivar Burangrang, k3 : Kultivar Slamet

Faktor yang kedua merupakan dosis herbisida Toupan 220 AS yang terdiri dari : d1: $1,51 /$ ha, d2 : $31 /$ ha, d3 : 4,5/ha 
Pengamatan percobaan dilakukan terdiri dari pengamatan penunjang dan pengamatam utama. Pengamatan penunjang (tidak diuji secara statistik) adalah pengamatan terhadap cuaca, serangan hama dan penyakit, komposisi gulma sebelum aplikasi glifosat dengan menghitung Nilai Jumlah Dominasi. Sedangkan pengamatan utama dilakukan terhadap datadata yang diuji secara statistik, yang meliputi : bobot kering gulma per golongan dan total, tinggi tanaman kedelai, laju pertumbuhan tanaman kedelai, jumlah polong isi pertanaman, bobot biji per hektar, dan bobot 100 biji.

\section{Hasil dan Pembahasan}

Hasil uji pada taraf $5 \%$ terhadap bobot kering gulma rumput tidak memperlihatkan pengaruh interaksi antara kultivar kedelai dengan dosis herbisida glifosat terhadap bobot kering gulma rumput pada $2 \mathrm{mst}, 4 \mathrm{mst}, 6 \mathrm{mst}$ dan $8 \mathrm{mst}$. Secara mandiri masing-masing kultivar kedelai dan dosis herbisida glifosat terhadap bobot kering gulma rumput tersaji pada Tabel 1 .

Tabel 1. Pengaruh Dosis Herbisida Glifosat dan Kultivar Kedelai terhadap Bobot Kering Gulma Rumput pada 2 mst, 4 mst, 6 mst dan 8 mst.

\begin{tabular}{lcccc}
\hline \multirow{2}{*}{ Perlakuan } & \multicolumn{5}{c}{ Bobot Kering Gulma Rumput (gram) } \\
\cline { 2 - 5 } & $\mathbf{2}$ & $\mathbf{4}$ & $\mathbf{6}$ \\
\hline & $\mathbf{2}$ & $\mathbf{8}$ \\
\hline $\mathrm{K}_{1}$ & $1,56 \mathrm{a}$ & $0,87 \mathrm{a}$ & $3,24 \mathrm{a}$ & $3,54 \mathrm{a}$ \\
$\mathrm{K}_{2}$ & $1,48 \mathrm{a}$ & $1,22 \mathrm{a}$ & $2,92 \mathrm{a}$ & $3,85 \mathrm{a}$ \\
$\mathrm{K}_{3}$ & $1,15 \mathrm{a}$ & $1,11 \mathrm{a}$ & $2,60 \mathrm{a}$ & $3,65 \mathrm{a}$ \\
\hline Dosis Herbisida Glifosat & & \\
\hline $\mathrm{D}_{1}$ & $1,38 \mathrm{a}$ & $1,28 \mathrm{a}$ & $2,80 \mathrm{a}$ & $3,79 \mathrm{a}$ \\
$\mathrm{D}_{2}$ & $1,43 \mathrm{a}$ & $1,02 \mathrm{a}$ & $2,89 \mathrm{a}$ & $3,82 \mathrm{a}$ \\
$\mathrm{D}_{3}$ & $1,38 \mathrm{a}$ & $0,89 \mathrm{a}$ & $2,76 \mathrm{a}$ & $3,33 \mathrm{a}$ \\
\hline \hline
\end{tabular}

Keterangan: Nilai rata-rata perlakuan yang diikuti huruf yang sama (arah vertikal) tidak berbeda nyata berdasarkan Uji Jarak Berganda Duncan pada taraf $5 \%$.

Pada Tabel 1 terlihat bahwa secara mandiri perlakuan kultivar maupun dosis herbisida glifosat memberikan pengaruh yang tidak berbeda nyata terhadap bobot kering gulma rumput pada 2 mst, 4 mst, 6 mst dan 8 mst.

Hasil uji memperlihatkan tidak terdapat pengaruh interaksi antara kultivar kedelai dengan dosis herbisida glifosat terhadap bobot kering gulma daun lebar pada 2 mst, 4 mst, 6 mst dan 8 mst. Secara mandiri masing-masing kultivar kedelai dan dosis herbisida glifosat terhadap bobot kering gulma daun lebar tersaji pada Tabel 2.

Pada Tabel 2 terlihat bahwa secara mandiri perlakuan kultivar memberikan pengaruh yang tidak berbeda nyata terhadap bobot kering gulma daun lebar pada 2 mst. Sedangkan pada 4 mst, 6 mst, dan 8 mst perlakuan kultivar memberikan pengaruh yang berbeda nyata. Berbeda dengan perlakuan kultivar, perlakuan dosis herbisida Glifosat tidak memberikan pengaruh yang nyata terhadap bobot kering gulma daun lebar pada 2 mst, 4 mst, 6 mst, dan 8 mst.

Kultivar Tidar memberikan pengaruh yang lebih tinggi terhadap bobot kering gulma daun lebar pada umur 4 mst dan 6 mst. Sedangkan pada umur 8 mst kultivar Burangrang yang memberikan pengaruh yang lebih baik tetapi tidak berbeda nyata dengan kultivar Slamet.

Tabel 2. Pengaruh Dosis Herbisida Glifosat dan Kultivar Kedelai terhadap Bobot Kering Gulma Berdaun Lebar pada 2 mst, 4 mst, 6 mst dan 8 mst.

\begin{tabular}{lcccc}
\hline \multirow{2}{*}{ Perlakuan } & \multicolumn{5}{c}{ Bobot Kering Gulma Berdaun lebar } \\
& \multicolumn{5}{c}{ Umur (mst) } \\
\cline { 2 - 5 } & $\mathbf{2}$ & $\mathbf{4}$ & $\mathbf{6}$ & $\mathbf{8}$ \\
\hline \multicolumn{5}{c}{ Kultivar Kedelai } \\
\hline $\mathrm{K}_{1}$ & $1,84 \mathrm{a}$ & $52,82 \mathrm{~b}$ & $37,04 \mathrm{~b}$ & $28,24 \mathrm{a}$ \\
$\mathrm{K}_{2}$ & $1,65 \mathrm{a}$ & $27,20 \mathrm{a}$ & $31,89 \mathrm{ab}$ & $41,17 \mathrm{~b}$ \\
$\mathrm{~K}_{3}$ & $2,19 \mathrm{a}$ & $37,30 \mathrm{a}$ & $23,87 \mathrm{a}$ & $40,09 \mathrm{~b}$ \\
\hline Dosis Herbisida Glifosat \\
\hline $\mathrm{D}_{1}$ & $2,57 \mathrm{a}$ & $39,59 \mathrm{a}$ & $33,69 \mathrm{a}$ & $36,86 \mathrm{a}$ \\
$\mathrm{D}_{2}$ & $1,39 \mathrm{a}$ & $35,15 \mathrm{a}$ & $27,94 \mathrm{a}$ & $34,47 \mathrm{a}$ \\
$\mathrm{D}_{3}$ & $1,73 \mathrm{a}$ & $32,59 \mathrm{a}$ & $31,17 \mathrm{a}$ & $38,17 \mathrm{a}$ \\
\hline \hline
\end{tabular}

Keterangan: Nilai rata-rata perlakuan yang diikuti huruf yang sama (arah vertikal) tidak berbeda nyata berdasarkan Uji Jarak Berganda Duncan pada taraf $5 \%$.

Hasil analisis tidak memperlihatkan pengaruh interaksi antara kultivar kedelai dengan dosis herbisida glifosat terhadap bobot kering gulma total pada $2 \mathrm{mst}, 4 \mathrm{mst}, 6 \mathrm{mst}$ dan 8 mst. Secara mandiri masing-masing kultivar kedelai dan dosis herbisida Glifosat terhadap bobot kering gulma total tersaji pada Tabel 3 .

Pada Tabel 3 terlihat bahwa secara mandiri perlakuan kultivar memberikan pengaruh yang tidak berbeda nyata terhadap bobot kering gulma total pada $2 \mathrm{mst}$, dan $8 \mathrm{mst}$. Sedangkan pada 4 mst dan 6 mst, perlakuan kultivar mem- 
berikan pengaruh yang berbeda nyata. Berbeda dengan perlakuan kultivar, perlakuan dosis herbisida glifosat tidak memberikan pengaruh yang nyata terhadap bobot kering gulma total pada $2 \mathrm{mst}, 4 \mathrm{mst}$, dan $6 \mathrm{mst}$. Perlakuan ini baru memberikan pengaruh yang berbeda nyata terhadap bobot kering gulma total pada umur 8 mst.

Tabel 3. Pengaruh Dosis Herbisida Glifosat dan Kultivar Kedelai terhadap Bobot Kering Gulma Total pada 2 mst, 4 mst, 6 mst dan 8 mst.

\begin{tabular}{lcccc}
\hline \hline & \multicolumn{4}{c}{ Bobot Kering Gulma Total (gram) } \\
\cline { 2 - 5 } Perlakuan Umur (mst) \\
\cline { 2 - 5 } & $\mathbf{5}$ & $\mathbf{6}$ \\
\hline \multicolumn{4}{c}{ Kultivar Kedelai } \\
\hline $\mathrm{K}_{1}$ & $2,61 \mathrm{a}$ & $56,62 \mathrm{~b}$ & $50,38 \mathrm{~b}$ & $46,31 \mathrm{a}$ \\
$\mathrm{K}_{2}$ & $2,25 \mathrm{a}$ & $28,92 \mathrm{a}$ & $47,15 \mathrm{~b}$ & $44,19 \mathrm{a}$ \\
$\mathrm{K}_{3}$ & $2,90 \mathrm{a}$ & $31,53 \mathrm{a}$ & 27,22 & $43,90 \mathrm{a}$ \\
\hline Dosis Herbisida Glifosat \\
$\mathrm{D}_{1}$ & $2,88 \mathrm{a}$ & $44,39 \mathrm{a}$ & $41,22 \mathrm{a}$ & $45,06 \mathrm{a}$ \\
$\mathrm{D}_{2}$ & $2,50 \mathrm{a}$ & $35,00 \mathrm{a}$ & $41,02 \mathrm{a}$ & $56,61 \mathrm{~b}$ \\
$\mathrm{D}_{3}$ & $2,38 \mathrm{a}$ & $36,69 \mathrm{a}$ & $42,51 \mathrm{a}$ & $42,73 \mathrm{a}$ \\
\hline \hline
\end{tabular}

Keterangan: Nilai rata-rata perlakuan yang diikuti huruf yang sama (arah vertikal) tidak berbeda nyata berdasarkan Uji Jarak Berganda Duncan pada taraf $5 \%$.

Kultivar Tidar memberikan pengaruh yang lebih tinggi terhadap bobot kering gulma daun lebar pada umur 4 mst. Pada umur $6 \mathrm{mst}$ kultivar ini juga memberikan pengaruh yang lebih baik tetapi tidak berbeda nyata dengan kultivar Burangrang. Dosis $31 /$ ha (d2) memberikan pengaruh yang lebih tinggi terhadap bobot gulma total pada umur 8 mst.

Hasil analisis memperlihatkan tidak terdapat pengaruh interaksi antara kultivar kedelai dengan dosis herbisida glifosat terhadap tinggi tanaman kedelai pada 2 mst dan 4 mst. Sedangkan Hasil uji pada taraf $5 \%$ terhadap tinggi tanaman kedelai pada $6 \mathrm{mst}$ dan $8 \mathrm{mst}$ memperlihatkan pengaruh interaksi antara kultivar kedelai dengan dosis herbisida glifosat terhadap tinggi tanaman kedelai pada $6 \mathrm{mst}$ dan 8 mst.

Secara mandiri masing-masing kultivar kedelai dan dosis herbisida glifosat terhadap tinggi tanaman kedelai pada 2 mst dan $4 \mathrm{mst}$ tersaji pada Tabel 4.

Pada Tabel 4 terlihat bahwa secara mandiri kultivar Burangrang memberikan pengaruh yang lebih baik terhadap tinggi tanaman umur 2 mst. Begitupun pada umur 4 mst kultivar
Burangrang memberikan pengaruh yang lebih baik tetapi tidak berbeda nyata dengan kultivar Slamet. Sedangkan perlakuan dosis herbisida glifosat tidak memberikan pengaruh yang berbeda nyata terhadap tinggi tanaman umur 2 mst dan 4 mst.

Tabel 4. Pengaruh Dosis Herbisida Glifosat dan Kultivar Kedelai terhadap Tinggi Tanaman Kedelai pada 2 mst dan 4 mst.

\begin{tabular}{lcc}
\hline \multirow{2}{*}{ Perlakuan } & \multicolumn{2}{c}{ Tinggi Tanaman Kedelai (cm) } \\
\cline { 2 - 3 } & \multicolumn{2}{c}{ Umur (mst) } \\
\cline { 2 - 3 } & \multicolumn{2}{c}{$\mathbf{4}$} \\
\hline Kultivar Kedelai & $22,44 \mathrm{a}$ \\
$\mathrm{K}_{1}$ & $12,22 \mathrm{a}$ & $29,17 \mathrm{~b}$ \\
$\mathrm{~K}_{2}$ & $15,04 \mathrm{c}$ & $28,57 \mathrm{~b}$ \\
$\mathrm{~K}_{3}$ & $13,17 \mathrm{~b}$ & \\
\hline Dosis Herbisida Glifosat & $25,56 \mathrm{a}$ \\
\hline $\mathrm{D}_{1}$ & $13,35 \mathrm{a}$ & $25,84 \mathrm{a}$ \\
$\mathrm{D}_{2}$ & $13,05 \mathrm{a}$ & $25,78 \mathrm{a}$ \\
$\mathrm{D}_{3}$ & $14,03 \mathrm{a}$ & \\
\hline \hline
\end{tabular}

Keterangan: Nilai rata-rata perlakuan yang diikuti huruf yang sama (arah vertikal) tidak berbeda nyata berdasarkan Uji Jarak Berganda Duncan pada taraf $5 \%$.

Pada Tabel 5 terlihat bahwa pada kultivar Tidar dosis herbisida glifosat 4,5 1/ha (d3) menghasilkan tinggi tanaman kedelai yang lebih tinggi pada umur 6 mst. Pada kultivar Burangrang perlakuan penambahan dosis tidakmemberikan pengaruh yang berbeda nyata. Sedangkan pada kultivar Slamet perlakuan 4,5 1/ha (d3) menghasilkan tinggi tanaman yang lebih tinggi tetapi tidak berbeda nyata dengan perlakuan $3,01 /$ ha $(\mathrm{d} 2)$.

Tabel 5. Pengaruh Dosis Herbisida Glifosat dan Kultivar Kedelai terhadap Tinggi Tanaman Kedelai pada 6 mst.

\begin{tabular}{cccc}
\hline \multirow{2}{*}{$\begin{array}{c}\text { Kultivar } \\
\text { Kedelai }\end{array}$} & \multicolumn{3}{c}{ Dosis Herbisida Glifosat (1/ha) } \\
\cline { 2 - 4 } & $\mathbf{D}_{\mathbf{1}}$ & $\mathbf{D}_{\mathbf{2}}$ & $\mathbf{D}_{\mathbf{3}}$ \\
& $\mathbf{( 1 , 5 )}$ & $\mathbf{( 3 )}$ & $\mathbf{( 4 , 5 )}$ \\
\hline $\mathrm{K}_{1}$ & $31,28 \mathrm{ab}$ & $23,60 \mathrm{a}$ & $36,15 \mathrm{~b}$ \\
& $\mathrm{~A}$ & $\mathrm{~A}$ & $\mathrm{~A}$ \\
\hline $\mathrm{K}_{2}$ & $32,27 \mathrm{a}$ & $39,18 \mathrm{a}$ & $35,41 \mathrm{a}$ \\
& $\mathrm{A}$ & $\mathrm{B}$ & $\mathrm{A}$ \\
\hline $\mathrm{K}_{3}$ & $28,83 \mathrm{a}$ & $39,92 \mathrm{~b}$ & $44,82 \mathrm{~b}$ \\
& $\mathrm{~A}$ & $\mathrm{~B}$ & $\mathrm{~A}$ \\
\hline \hline
\end{tabular}

Keterangan: Nilai rata-rata yang ditandai huruf kecil yang sama (arah vertikal) dan huruf kapital yang sama (arah horizontal) tidak berbeda nyata menurut Uji Jarak Berganda Duncan $5 \%$. 
Pada dosis herbisida glifosat 1,5 1/ha (d1) dan 4,5 1/ha (d2) ketiga kultivar memberikan pengaruh yang tidak berbeda nyata. Sedangkan dosis 3 1/ha (d2) kultivar Slamet memberikan pengaruh yang terbaik tetapi tidak berbeda nyata dengan kultivar Burangrang.

Pada Tabel 6 terlihat bahwa pada kultivar Tidar dosis herbisida Glifosat 4,5 1/ha (d3) memberikan tinggi tanaman kedelai yang lebih tinggi pada umur 8 mst tetapi tidak berbeda nyata dengan dosis $3 \mathrm{l}$ /ha (d2). Pada kultivar Burangrang perlakuan penambahan dosis tidak memberikan pengaruh yang berbeda nyata. Sedangkan pada kultivar Slamet perlakuan dosis 31 /ha menghasilkan tinngi tanaman yang lebih tinggi.

Pada dosis herbisida glifosat 1,5 1/ha (d1) dan 4,5 1/ha (d2) ketiga kultivar memberikan pengaruh yang tidak berbeda nyata. Sedangkan dosis 3 1/ha (d2) kultivar Slamet memberikan pengaruh yang terbaik tetapi tidak berbeda nyata dengan kultivar Burangrang.

Tabel 6. Pengaruh Dosis Herbisida Glifosat dan Kultivar Kedelai terhadap Tinggi Tanaman Kedelai pada 8 mst.

\begin{tabular}{cccc}
\hline \hline \multirow{2}{*}{$\begin{array}{c}\text { Kultivar } \\
\text { Kedelai }\end{array}$} & \multicolumn{3}{c}{ Dosis Herbisida Glifosat (1/ha) } \\
\cline { 2 - 4 } & $\mathrm{D}_{1}$ & $\mathbf{D}_{2}$ & $\mathbf{D}_{3}$ \\
\hline $\mathrm{K}_{1}$ & $41,33 \mathrm{~b}$ & $28,57 \mathrm{a}$ & $47,18 \mathrm{~b}$ \\
& $\mathrm{~A}$ & $\mathrm{~A}$ & $\mathrm{~A}$ \\
\hline $\mathrm{K}_{2}$ & $42,60 \mathrm{a}$ & $41,58 \mathrm{a}$ & $40,73 \mathrm{a}$ \\
& $\mathrm{A}$ & $\mathrm{B}$ & $\mathrm{A}$ \\
\hline $\mathrm{K}_{3}$ & $38,44 \mathrm{a}$ & $49,82 \mathrm{~b}$ & $47,60 \mathrm{a}$ \\
& $\mathrm{A}$ & $\mathrm{B}$ & $\mathrm{A}$ \\
\hline
\end{tabular}

Keterangan: Nilai rata-rata yang ditandai huruf kecil yang sama (arah vertikal) dan huruf kapital yang sama (arah horizontal) tidak berbeda nyata menurut Uji Jarak Berganda Duncan 5 \%.

Pengaruh perlakuan terhadap hasil dan komponen hasil dapat disimak pada Tabel 7 . Dari Tabel 7 dapat terlihat bahwa pada kultivar Slamet memberikan jumlah polong isi pertanaman yang lebih terbanyak tetapi tidak berbeda nyata dengan kultivar Burangrang. Dosis herbisida Glifosat 31/ha (d2) memberikan jumlah polong isi yang terbanyak (d3).

Sedangkan untuk bobot per petak dan bobot per hektar kultivar Burangrang memberikan pengaruh yang terbaik. Dosis 31 /ha (d2) juga memberikan pengaruh yang terbaik tetapi tidak berbeda nyata dengan dosi 4,5 1/ha (d3).

Kultivar Burangrang memberikan bobot 100 biji yang lebih besar. Sedangkan perlakuan penambahan dosis tidak memberikan pengaruh yang berbeda nyata terhadap bobot 100 biji.

Tabel 7. Pengaruh Dosis Herbisida Glifosat dan Kultivar Kedelai terhadap Komponen Hasil Tanaman Kedelai.

\begin{tabular}{lcccc}
\hline \hline \multicolumn{5}{c}{ Dosis Herbisida Glyfosat } \\
Perlakuan & $\begin{array}{c}\text { Jumlah } \\
\text { polong } \\
\text { isi per } \\
\text { tanaman }\end{array}$ & $\begin{array}{c}\text { Bobot } \\
\text { per } \\
\text { petak } \\
\text { (gram) }\end{array}$ & $\begin{array}{c}\text { Bobot } \\
\text { per } \\
\text { hektar } \\
\text { (ton) }\end{array}$ & $\begin{array}{c}\text { Bobot } \\
\text { 100 biji } \\
\text { (gram) }\end{array}$ \\
\hline Kultivar Kedelai \\
$\mathrm{K}_{1}$ & $13,64 \mathrm{a}$ & $94,9 \mathrm{a}$ & $0,95 \mathrm{a}$ & $12,03 \mathrm{a}$ \\
$\mathrm{K}_{2}$ & $15,30 \mathrm{~b}$ & $200,15 \mathrm{c}$ & $2,01 \mathrm{c}$ & $21,82 \mathrm{~b}$ \\
$\mathrm{~K}_{3}$ & $15,35 \mathrm{~b}$ & $167,76 \mathrm{~b}$ & $1,68 \mathrm{~b}$ & $16,06 \mathrm{c}$ \\
\hline Dosis Herbisida Glifosat & & \\
$\mathrm{D}_{1}$ & $13,64 \mathrm{a}$ & $134,62 \mathrm{a}$ & $1,35 \mathrm{a}$ & $16,50 \mathrm{a}$ \\
$\mathrm{D}_{2}$ & $16,86 \mathrm{~b}$ & $165,62 \mathrm{~b}$ & $1,66 \mathrm{~b}$ & $16,71 \mathrm{a}$ \\
$\mathrm{D}_{3}$ & $13,79 \mathrm{a}$ & $163,16 \mathrm{~b}$ & $1,63 \mathrm{~b}$ & $16,69 \mathrm{a}$ \\
\hline \hline
\end{tabular}

Keterangan: Nilai rata-rata perlakuan yang diikuti huruf yang sama (arah vertikal) tidak berbeda nyata berdasarkan Uji Jarak Berganda Duncan pada taraf $5 \%$.

Semua kombinasi perlakuan antara kultivar dan dosis herbisida glifosat tidak memberikan pengaruh interaksi terhadap keberadaan gulma. Infestasi gulma tetap ada walupun aplikasi herbisida telah dilakukan. Jenis gulma yang paling dominan berada pada areal pertanaman adalah jenis gulma dari golongan berdaun lebar (Broad-leave). Hal ini disebabkan karena herbisida dengan berbahan aktif Glifosat tidak dapat mematikan biji-biji gulma dalam tanah, biji-biji gulma berdaun lebar mempunyai masa dormansi lama dalam tanah dan jumlahnya banyak, sehingga setelah aplikasi herbisida Glifosat pertanaman akan didominasi gulma berdaun lebar (Broad-leave) (Anwar M. Sabur, 2003).

Selain masih adanya infestasi gulma, kombinasi perlakuan antara kultivar dan dosis herbisida glifosat juga membuat jumlah infestasi gulma terus meningkat terutama ketika masa peride kritis telah berakhir sampai menjelang waktu pemanenan. Hal ini disebabkan karena gulma tersebut merupakan gulma yang tumbuh baru dari biji yang berkecambah, sehingga bobot kering gulma total pada setiap plot perlakuan berbeda nyata dan selalu bertambah serta akan selalu berasosiasi negatif dengan tanaman kedelai dalam hal pengambilan unsur hara, air, ruang tumbuh, $\mathrm{CO}_{2}$, dan cahaya matahari. Selain itu penelitian ini juga dilakukan pada musim 
kemarau sehingga infestasi gulmanya tidak sebanyak musim penghujan.

Kombinasi perlakuan kultivar dan dosis herbisida glifosat tidak menunjukan adanya interaksi pada tinggi tanaman umur 2 mst dan 4 mst, hal ini disebabkan pada awal masa pertumbuhan kompetisi persaingan tinggi. Periode kritis ini diatasi dengan aplikasi herbisida glifosat pada awal penanaman sehingga jumlah gulma yang ada pada periode ini relatif rendah.

Sedangkan pada umur 6 mst dan 8 mst kombinasi perlakuan kultivar dan dosis herbisida glifosat menunjukan adanya interaksi. Hal ini disebabkan muncunya pertumbuhan gulma baru.

Sama halnya dengan tinggi tanaman pada laju pertumbuhan tanaman interaksi antara kultivar dengan dosis herbisida glifosat tidak terjadi ketika awal penanaman (2-4 mst) hal ini dikarenakan masih dalam periode kritis sehingga persaingan dengan gulmanya masih relatif tinggi. Tetapi ketika umur lanjut (4-6 mst dan 6-8 mst) munculnya gulma-gulma baru yang tumbuh sehingga kompetisi persaingan unsur hara, air, dan cahaya antara gulma dan tanaman kedelai semakin tinngi. Hal inilah yang menyebabkan adanya interaksi antara kultivar dan dosis herbisida glifosat terhadap laju pertumbuhan tanaman 4-6 mst dan 6-8 mst).

Bobot biji per petak yang kemudian dikonversikan menjadi bobot per hektar, yang terbesar dihasilkan oleh kultivar Burangrang hal ini disebabkan karena persentase pencapaian produksi kultivar ini paling besar bila dibandingkan kultivar yang lain. Semakin besar ukuran biji sem. Selain Kultivar Burangrang dosis $3 \mathrm{l} /$ ha (d2) juga memberikan bobot yang paling besar. Hal ini dikarenakan dosis ini dapat mengendalikan gulma secara optimum. Kondisi awal penanaman menentukan produktivitas dari tanaman tersebut.

Bobot 100 biji hanya di pengaruhi oleh kultivar saja. Bobot 100 biji menentukan ukuran dari biji itu sendiri. Oleh karena itu bobot seratus bji tidak dipengaruhi oleh dosis herbisida karena berasal dari kemampuan gen (internal) tanaman itu sendiri.

\section{Kesimpulan dan Saran}

\section{Kesimpulan}

1. Kombinasi perlakuan kultivar dan dosis herbisida glifosat tidak memberikan pengaruh interaksi terhadap bobot kering gulma rumput,bobot kering daun lebar, bobot gulma total, tinggi tanaman 2 mst dan 4 mst, serata komponen hasil.

2. Kombinasi perlakuan kultivar dan dosis herbisida glifosat menunjukan adanya interaksi pada tinggi tanaman umur $6 \mathrm{mst}$ dan 8 mst serta pada laju pertumbuhan 4-6 mst dan 6-8 mst.

3. Kultivar Burangrang dan dosis herbisida glifosat $31 /$ ha memberikan pengaruh yang terbaik dilihat dari segi komponen hasil.

\section{Saran}

Perlu dilakukan penelitian lebih lanjut dengan dosis yang sama tetapi frekuensi aplikasi yang berbeda

\section{Daftar Pustaka}

Ashton, F.M. and A.S. Craft. 1981. Made of Action of Herbicides. $2^{\text {nd }}$ ed. John Wiley and Sons. New York.

Gunadi A. 2006. Pengaruh kascing, pupuk kotoran ayam, dan kompos kulit buah kakao sebagai campuran media tanam terhadap bibit kakao (Theobroma cacao L) kultivar Upper Amazone Hybrid (UAH).

Sabur A.M. 2003. Pengendalian gulma dengan serasah pangkasan dan rotasi herbisida di perkebunan teh. Efisiensi penggunaan herbisida glifosat pada penerapan teknologi sonic bloom. Pros. Konf. Nas. XVI HIGI Jilid 2 Bogor, 15-17 Juli.

Supriyo A., B. Prayudi dan D. Nazemi. 1996. Pengelolaan Gulma Pada Tanaman Kedelai Pada Lahan Gambut di Kalimantan. Pros. II Konf. Nas. XII dan Seminar Ilmiah HIGI.

Widayat D. 1996. Kemampuan berkompetisi kedelai (Glycine max), kacang tanah (Arachis hypogea) dan kacang hijau (Vigna radiaic) terhadap teki (Cyperus rotundus). Jurnal Bionatura, Juli 2002. Vol. 4 No. 2. hal 118-128

Widayat D., Sumadi dan Y. Sumekar. 2002. Pengaruh campuran herbisida pendimetalin dengan alachlor terhadap gulma pada tanaman kedelai. Jurnal Kultivasi, Vol. 1 No 2. hal 10-19 